\title{
Theorizing CSR Reporting: A Discursive Institutionalism Framework
}

\author{
Muatasim Ismaeela \\ aUniKL Business School, University of Kuala Lumpur, Malaysia, muatasim.ismaeel@gmail.com
}

Received: 15 October 2018, accepted: 18 October 2018, published: 3 March 2019

\begin{abstract}
Although CSR reporting is a well-established business practice now, it is still an emerging genre that lacks convergence and standardization. Different theoretical perspectives are used to study CSR reporting. These perspectives agree on the instrumental nature of CSR reporting, while they vary in the aspects of the practice they emphasize and in their normative assumptions. Using 'Discursive Institutionalism' as a theoretical lens, different practices in the field can be incorporated in the proposed framework to reach a comprehensive understanding of CSR reporting phenomenon. The paper aims to propose a theoretical framework for CSR reporting research that enables a holistic and comprehensive explanation that is inclusive of different practices and normative assumptions in the field. The proposed framework utilizes new developments in Institutional Theory that emphasize multiple institutional logics, the hybridity of social practices, the role of social agents, and the discursive aspect of institutions. The proposed theoretical framework adds a new comprehensive perspective to CSR reporting research. It provides a solid theoretical base for further investigation of different practices in the field.
\end{abstract}

Keywords: CSR reporting, Sustainability reporting, Institutional Theory, Discursive Institutionalism, Institutional Logics

\section{INTRODUCTION}

Corporate reporting on non-financial performance was there for decades as part of official corporate disclosure in annual reports. However, this practice gained momentum since the 1970s (Albers and Gunther, 2010; Fifka, 2013) and started to establish itself as a distinct practice from traditional financial disclosure. This distinction became apparent when companies began to publish stand-alone reports on corporate social and environmental issues. Consequently, CSR reporting gained the status of a distinct communication genre.

As an emerging practice, its boundaries and underlying concepts and assumptions keep evolving and changing. The practice is not fully institutionalized; it is in the process of institutionalization. Even titles of non-financial reports are not unified; Social Reporting, Environmental Reporting, Ethical Reporting, Corporate Social Responsibility (CSR) Reporting, Sustainability Reporting are just a few examples of the titles used in these reports. For practical considerations, we will use 'CSR reporting' to refer to non-financial reporting practice in this paper. Besides, the plurality is not limited to the names and titles of reports; even the scope of CSR reporting is not well defined. During the past four decades, the scope of CSR reporting has been shifted from focusing on either environmental or social issues to a comprehensive scope under the notion of sustainability. The spread of sustainability notion accompanied the introduction of the 'Triple Bottom Line' concept that emphasizes economic as well as social and environmental dimensions of reporting (Fifka, 2013)

Academic research on CSR reporting is as diverse as the practice itself. There is a lack of consistency in theorizing CSR reporting. Research in this field is informed by different theoretical perspectives (Gray et al., 1995; Hooghiemstra, 2000; 
Parker, 2005; Williams, 2008). In general, those theoretical perspectives can be classified into two major groups: economic and political theories. While economic theories focus on the economic utility of CSR reporting and look at it from the perspective of agency or decision usefulness theories (Gray et al., 1995) or from an understanding of legitimacy theory from a resource based or reputation risk perspectives (Bebbington et al., 2008; Bebbington et al., 2009), political theories look to CSR reporting as a social legitimacy tool based on social contract, stakeholders' relations or institutional perspectives (Gray et al., 1995).

The early efforts in CSR reporting research were derived from accounting traditions under the label of 'Social and Environmental Accounting' (Parker, 2005; Williams, 2008) and were motivated mainly by a normative view of CSR reporting as part of corporate accountability toward stakeholders and the whole society. However, this normative view is not supported by empirical findings (Bebbington et al., 2008; Adams, 2008). Consequently, different streams of research have emerged to explain CSR reporting practice as it is, and to explain the perceived failure of its normative aspirations. The critical stream of research focuses on uncovering the power relations and instrumental motives behind CSR reporting and looks to this practice as a 'hypocrisy' action of 'greenwashing' or 'window dressing' (Gray, 2006; Brown and Fraser, 2006). While managerialist stream of research looks to CSR reporting as part of corporate communication practices that are teleological in nature (Reynolds and Yuthas, 2008) and are motivated by improving company performance and shareholders' value (Gray, 2006).

In fact, the different theoretical perspectives and approaches should not be treated as competing explanations of CSR reporting (Gray et al., 1995). This "pluralism in theoretical lenses and methodologies applied to common research problems can yield incremental and accumulating insights that are enriched by both commonality and difference" (Parker, 2005, p. 849). Gray et al. (1995) stated that the differences between social and political theories in this area of research are "differences in levels of resolution of perception rather than arguments for and against competing theories as such" (Gray et al., 1995, p. 52). This understanding of theoretical plurality leads to the appreciation of multidisciplinary research perspectives that call for a more holistic understanding of CSR reporting (Williams, 2008).

This paper proposes that a holistic understanding of CSR reporting that is broad in scope and resolution can result from emphasizing the institutionalization process of CSR reporting and focusing on agency-structure interaction in this emerging field. The paper highlights the potential of new developments in Institutional Theory that emphasize institutional plurality, hybridity in social practices, the multiplicity of institutional logics and the importance of symbolic and linguistic representations of these competing logics. Such a holistic perspective includes the different theoretical perspectives within the same framework as each of them reflects one of the various institutional logics that influence actors to comply with specific institutional arrangements, or are used by actors to alter institutional arrangements.

The paper continues as follows: the second section provides a review of the main research perspectives used in CSR reporting research with emphasis on 'critical' and 'managerialist' perspectives. The third section includes discussion of Institutional Theory and how it is used in CSR reporting research, before introducing 'Discursive Institutionalism' and a proposed theoretical framework for CSR reporting research in the fourth section. Methodological issues in future research are discussed in the fifth section, while the paper's main conclusion is presented in the sixth section.

\section{Critical vs. Managerialist research perspectives:}

With the expansion of annual reports to include voluntary information in addition to the mandatory regulated content, researchers started to give attention to the voluntary parts of annual reports to explore the interests of companies and the priorities of their management (Gray et al., 1995; Guthrie and Abeysekera, 2006). This research interest gained more importance with the emergence of stand-alone CSR reports given the dedication of time, effort, and cost by companies to publish them and the more comprehensive attention to several social and environmental topics (Albers and Gunther, 2010). This voluntary disclosure is of a strategic nature (Williams, 2008); companies use voluntary disclosure to achieve specific ends. Stanton and Stanton (2002) classify the different perspectives that are used to study and explain voluntary disclosure into two main categories; those perspectives that look to voluntary disclosure as a proactive action and others that look at it as a reactive action. According to them, political economy, marketing, and image building perspectives assume proactive nature of voluntary disclosure; companies want to influence and shape their image and relations with stakeholders and society. On the other hand, CSR, legitimacy, and accountability perspectives assume a reactive nature of voluntary disclosures; companies respond to stakeholders and social concerns by disclosing voluntary information (Stanton and Stanton, 2002). Other researchers propose similar classifications; organizational vs. strategic legitimacy (Chen and Roberts, 2010), societal view vs. managerialist view (Gond and Herrbach, 2006), normative vs. managerialist (or positivist) stakeholder theory (Deegan, 2002). While other researchers proposed three categories of CSR reporting research perspectives: business case approach, stakeholder-accountability approach and critical theory approach (Brown 
and Fraser, 2006), or managerialist approach, triple bottom line (TBL) approach, and ecologically and eco-justice informed approach (Gray, 2006). The differences among research perspectives can be attributed to the research orientation whether it is normative and concerned with what a company 'should' do in CSR reporting or it is explanatory and concerned with what a company 'is' doing in CSR reporting. Also, researchers' worldviews and ideologies affect their perspectives. Since this paper is concerned with the explanatory question, the two main explanatory perspectives; 'critical' and 'managerialist' are discussed.

\subsection{Critical Perspective on CSR Reporting}

The notion of 'Accountability' is central in critical studies of CSR reporting. 'Accountability' is defined as the duty to provide an account of those actions for which one is held responsible (Gray et al., 2014) or simply: giving an account to stakeholders (Adams, 2004). In fact, CSR reporting can be seen as a sign of expanding corporate accountability from the narrow scope of accountability toward shareholders to the broader scope of accountability toward stakeholders (Stanton and Stanton, 2002). Adams (2008) argued that accountability is a desired attribute of CSR reporting, while the achievement of this desired attribute is unlikely. Thus, the transparency and the real value of CSR reports to stakeholders is questioned and there is a common critique among academics and civil society organizations that Social and Environmental Reporting "is driven more by concerns with legitimacy, stakeholder management and masking conflict than by accountability" (Spence, 2007, p. 856).

In addition to 'Accountability', the notion of 'Sustainability' is used by researchers to critically reflect on the claims of CSR reporting (Deegan, 2002; Spence, 2007; Gray, 2010; Boiral and Henry, 2017). Gray (2010) stated that "most business reporting on sustainability and much business representative activity around sustainability actually have little, if anything to do with sustainability" (Gray, 2010, p. 48). He even questioned the possibility of assigning sustainability responsibilities to companies since sustainability issues are broader in their scope than companies' business activities (Gray, 2010).

It is prevalent in the literature that companies use CSR reports for public relations, impression management, and reputation purposes rather than to meet accountability and transparency requirements (Hooghiemstra, 2000; Idowu and Towler, 2004; Adams, 2008; Owen, 2008). This position is supported by the findings in previous studies that companies report on good news and are reluctant to report bad news; a practice reflect a 'self-laudatory' nature of CSR reports (Hackston and Milne, 1996; Hooghiemstra, 2000). Reynolds and Yuthas (2008) used validity claims in Habermas communicative action theory to study the degree of validity and reliability of communication in CSR reports. They argued that these validity claims cannot be taken for granted in corporate communication in general and in CSR reports specifically.

Critical studies are commonly built on the fact that accountability is conditioned by power relations; if stakeholders have no power to hold companies accountable for their actions, accountability cannot be achieved (Adams, 2008; Reynolds and Yuthas, 2008; Morf et al., 2013). According to Owen (2008), 'Accountability' is a radical concept and business leaders are reluctant to be held accountable for their actions; however, they utilize CSR reporting for reputation enhancement and risk management and consider it as an extension to financial reporting to investors. The dominant discourse among companies presents concepts like 'CSR', 'Accountability' and 'Sustainability' as congruent with 'business as usual' practices (Adams, 2004; Spence, 2007; Owen, 2008; Gray, 2010). This management 'capture' of the normative -and to an extent 'radical'- concepts and the 'institutionalization' of CSR reporting within the capitalist doctrine of profitmaximization is a central argument in critical research (Mathews, 1997; Owen, 2008).

\subsection{Managerialist Perspective on CSR Reporting}

Managerialist perspective does not challenge the 'business as usual' view of CSR reporting. In this perspective, CSR reporting is perceived as an instrument to achieve business objectives or as a by-product of those objectives (Gond and Herrbach, 2006). CSR reporting is considered as part of corporate communication practice which is "oriented toward teleological action - it is a means for achieving desired corporate ends" (Reynolds and Yuthas, 2008, p. 54). Researchers differ in defining these desired corporate ends. In social accounting research, CSR reporting is commonly perceived as aiming to build, restore, or enhance the legitimacy of company's actions, while from corporate communication perspective; the perceived aim of CSR reporting is to protect or enhance company's image and reputation (Hooghiemstra, 2000). Bebbington et al. (2008) proposed that "the purposes of CSR reporting may have more to do with the manufacture of an identity and self-presentation than with communication/accountability purposes or managerial perceptions of reputation" (Bebbington et al., 2008, p. 346). They argued that social and environmental matters may affect reputation "which then itself has a second order impact on the legitimacy of the organisation" while "legitimacy has deeper 
institutional roots than CSR reporting requirements" (Bebbington et al., 2008, p. 345). This absence of deeper institutional roots in the case of CSR reporting led to explanations of CSR reporting that are congruent with the 'business case' and 'profit making' orientations. For example, Branco and Rodrigues (2008) proposed "a theoretical framework combining legitimacy theory and a resource-based perspective" to explain CSR reporting by Portuguese listed companies (Branco and Rodrigues, 2008, p. 685). Other researchers propose image enhancement, credibility, reputation (Adams, 2002; Laine, 2009; Bhatia, 2012; Aiezza, 2015) or following the trends (Idowu and Towler, 2004; Amran and Siti Nabiha, 2009) as possible motives of CSR reporting. In addition, when looking to CSR reporting from stakeholders' relations perspective, it is argued that what companies do is stakeholders' management rather than stakeholders' engagement (Adams, 2002; Belal, 2002; Manetti, 2011).

In fact, the two perspectives are not contradicting. Both perspectives look to CSR reporting as an instrument to achieve business objectives. The main difference between the two perspectives is the underlying normative assumptions; 'corporate accountability' in critical studies and 'business case' in managerialist studies. However, both perspectives focus on corporate actions with little attention to the wider social context of those actions. To incorporate social context in CSR reporting research, 'Institutional Theory' has been used by some researchers. The following section elaborate on the use of 'Institutional Theory' in this area of research before presenting 'Discursive Institutionalism' as a new novel and comprehensive theoretical approach to study CSR reporting.

\section{Institutional Theory as a Theoretical lens for CSR Reporting Research:}

Corporate disclosure practices are part of business-society interactions (Deegan, 2002). Therefore, these interactions need to be incorporated in any effort to understand disclosure practices. System-oriented theories like legitimacy theory, stakeholders' theory, political economy theory, institutional theory and resource-based view are useful in this sense. They look to economic, political, social and institutional issues as inseparable (Deegan, 2002; Chen and Roberts, 2010). Among these theories, legitimacy theory is the most prevalent one in CSR reporting research especially by social accounting researchers (Deegan, 2002; Bebbington et al., 2008). Although it provides good understanding of certain aspects of corporate activity, some researchers have questioned its explanatory power (O'dwyer, 2002; Bebbington et al., 2008). However, considering the complexity of external and internal factors that influence CSR reporting may overcome the limitations of legitimacy theory (Adams, 2002; Bebbington et al., 2008).

Institutional theory is useful in incorporating complexity when explaining social phenomena. It is a proper choice to investigate a specific corporate practice "that is commonly implemented by other similar organizations as a part of normal business operations" (Chen and Roberts, 2010, p. 662) which is the case in CSR reporting. According to institutional theory, corporations are embedded in a nexus of formal and informal rules (Jackson and Apostolakou, 2010). As a practice, CSR reporting is affected by various institutional forces; for example, globalization, regulations, responsible investors, and sustainability rating.

Among the various variants of Institutional Theory, the sociological tradition in Neo-Institutional Theory has clear influence in business research and organizational studies, since it focuses on understanding how organizations act within and as part of the broader institutional context (Bondy, 2008). This theoretical tradition emphasizes how culturally legitimate models of organization and action constitute social actions (Clemens and Cook, 1999; Green and Li, 2011). Traditionally, Institutional Theory is used to study the diffusion of social and organization practices as a result of the regulative, normative, and cognitive aspects of the institutional environment (Jamali, 2010). In CSR Reporting, the three types of institutional forces influence companies to communicate and report on their social and environmental responsibilities. However, companies respond to institutional forces and their legitimacy challenges in different manners; they may adapt to the new expected practices, or they may act strategically by manipulating stakeholders' perception or engage in discourse with stakeholders to reach a mutual agreement (Erickson et al., 2011; Scherer et al. 2013). These differences in organizational responses to institutional forces enable the investigation of divergence and convergence in CSR reporting practices.

Some previous studies investigate the influence of different types of institutional forces on CSR reporting. For instance, Bebbington et al. (2009) found that a mix of normative and cognitive institutions was revealed by managers from reporting companies, while "coercive pressure was not strongly felt, and was easily accommodated within the existing business institutional framework" (Bebbington et al., 2009, p. 615). Pederson et al. (2013) found evidence supporting both coercive (regulative) and mimetic (cognitive) isomorphism in CSR reporting in Denmark. Other studies focused on the impact of different institutional contexts on CSR reporting. For instance, Hartman et al. (2007) compared CSR activities communication in US and European corporations. They found differences between the two groups of companies in the way used to justify their CSR activities; US-based companies use financial justifications while European 
companies use both financial and sustainability elements in their justification. They attribute these differences to the differences in the institutional contexts between the two groups of companies.

The mixed influences of different institutional contexts on CSR reporting activities receives more attention in developing countries, where companies operate within different influences from national and global contexts (Tang et al., 2014; Marano et al., 2017). In a study of MNC subsidiaries in Bangladesh, Momin and Parker (2013) found that what motivate those subsidiaries towards CSR reporting is their parent companies' practices and policies bot the local national institutions. Several researchers propose this explanation of CSR reporting in developing countries; CSR reporting in developing countries is considered as a mimetic action since it is considered as a 'global trend' or a 'best practice' (Azizul Islam and Deegan 2008; Amran and Siti- Nabiha 2009) or as a result of global pressure (Othman and Ameer, 2010).

However, even within the same national context CSR reporting practices may change as a result of changes in the institutional environment over time. Tengblad and Ohlsson (2010) analysed CEO letters in annual reports of Swedish companies over a long period to explore how CSR framing has been changed due to globalization of national business system. They reported changes in CSR discourse in the annual reports "from a national and communitarian view of social responsibility ... toward an international and individualistic view of social responsibility" (Tengblad and Ohlsson, 2010, $\mathrm{p}$. 653). Similar findings are presented by Laine (2009) in a longitudinal case study of a Finnish chemical company. He found that changes in social and institutional contexts were accompanied by major transitions in the environmental disclosure rhetoric. He concluded: "It is argued that the case company has adjusted its disclosures to respond to the varying institutional pressures in order to maintain a legitimate position in society" (Laine, 2009, p. 1029).

Other studies highlighted the link between the convergence and standardization of CSR reports and the development of global institutions in the field. This link was supported by de Villiers and Alexander (2014) findings of similar CSR reporting patterns among Australian and South African mining companies regardless their diverse settings and by Tang et al. (2014) findings of a trend toward convergence in CSR reporting as shown in their comparison between Chinese and US companies. Another study reported similarities in certain areas of CSR reporting among companies from different countries that are members in the Global Compact. However, the same study found variations between countries in reporting CSR issues other than those covered by the Global Compact (Chen and Bouvian, 2009).

In general, institutional research on CSR reporting is concerned mainly with identifying institutional forces that affect companies to publish CSR reports and influence the content of these reports. The dominant approach looks to social action as a result of social and institutional structures without giving enough attention to social agents and their ability to choose particular responses to structural effects or even to change them.

\section{A New Theoretical Framework for CSR Reporting Research}

\subsection{The Multiplicity of Institutional Logics and the Hybridity of Social Practices}

To an extent, traditional institutional perspectives emphasize social structures over managerial agency; they demonstrate the similarities among organizations that "mimic each other when practices become widely accepted and diffused. Relatively less work has explored how and why practices reach institutional status to engender such effects" (Bebbington et al., 2009, p. 589). In addition, focusing on managerial agency may lead to understanding how and why managers choose a certain strategic response to institutional processes. Oliver (1991) proposed five different strategic responses: Acquiesce, compromise, avoid, Defy and manipulate.

Common institutional approaches may explain similarities among organizations in specific fields, but they cannot completely explain the differences in organizational responses to institutional influences or the role of organizations (as agents) in changing institutional arrangements. Usually change is explained by external factors like technological development, shifting in political regimes, and globalization (Geppert et al., 2006; Bondy, 2008; Schmidt, 2010). New approaches in Institutional Theory give attention to the role of social agents in institutional change.

In real life, multiple institutional alternatives, each with its institutional logic intersect, overlap and compete for attention and adherence by social agents; some actors and actions will be constrained as a result of this interaction while others will be enabled, in most cases implicitly (Bondy, 2008). "The focus has thus shifted from the structural power of an institution to constrain agents and stabilize a field toward an appreciation of the power of agents to generate institutional conflict and change" (Levy et al., 2010, p. 92). The role of multiple institutional logics in the institutionalization process is explained by Green and Li (2011): 
"[a]s a new field evolves and institutionalizes, actors, as essentially institutional entrepreneurs, use rhetoric to negotiate, compromise, and reach agreement within the field, shaping the contest and competition of institutional logics. The emergence, evolution, and institutionalization of new fields are the product of these negotiations and agreements and often entail the rhetorical importation and exportation of institutional logics from one institutional field to another. Over time, field participants may arrive at a dominant vocabulary of motives or set of institutional logics that govern the field" (Green and Li, 2011).

During the institutionalization process, actors (social agents) in a specific field often have opposing perspectives rather than common ones. Therefore, there is a need to consider institutional conflict and change and not only institutional stability (Levy et al., 2010). Social agents act within plural and complex institutional environment with multiple institutional settings; this creates a space for discretionary behaviour for those agents (Bell, 2011). This process of institutional conflicts and change may create an 'institutional hybrid'. Boxenbaum (2006) stated that CSR field is an example of 'institutional hybrid', where different logics are interacting to shape organizational practice (Boxenbaum, 2006; Greenwood et al., 2011).

\subsection{Discursive Institutionalism}

Recently, there is a turn in Neo-Institutional Theory toward giving more attention to discursive and cognitive processes in the social construction of social action (Schmidt, 2010; Green and Li, 2011). This turn seems to introduce a new strand of Neo-Institutional Theory; it can be called 'Discursive Institutionalism' (Schmidt, 2010), 'Rhetorical Institutionalism' (Green and Li, 2011) or 'Constructivist Institutionalism' (Bell, 2011). The new strand which emphasizes language and meaning in institutional processes (Green and Li, 2011) emerged as the traditional Neo-Institutional theory started to endogenize institutional change (Schmidt, 2010; Bell, 2011). Bell (2011) argues that "the established positions are unable to explain institutional change effectively, largely because the agents in question are said to be highly constrained by their institutional environments" (Bell, 2011, p. 883). Thus alternative institutional accounts were proposed "featuring interpretive agents operating in relatively fluid ideational and discursive contexts to explain institutional change" (Bell, 2011, p. 883). It perceives institutional reality as subjective and experiential, and it aims to "explain how institutions both constrain and enable agency" (Green and Li, 2011, p. 1662).

The production of institutions as a social construction is mediated by discursive processes, where discourse is understood as the structures of meaning that are attached to social practices (Levy et al., 2010). The centrality of meanings in producing and maintaining institutions is clearly stated by Thelen and Steinmo (1992): "Institutions explain everything until they explain nothing" (Thelen and Steinmo, 1992, cited in Clemens and Cook, 1999, p. 442). Social agents' thoughts and behaviour are shaped by institutions through cognitive frames imposed by them (Bell, 2011; Campbell, 2007). According to Bell (2011), agents interpret and construct their understanding and experience of the institutional environment using subjective and inter-subjective cognitive frameworks and discursive processes; he argued that agents still have some degree of agential space within institutional settings so they can change institutions over time. Social agents are not passive in institutional contexts, their agency in influencing and may be changing social reality is practiced through their ability to interpret and translate institutional arrangements especially when applied in new fields. New research approaches that are concerned with studying agency within institutional frameworks emphasize the importance of discursive and cognitive processes of social agents' construction of their social reality and how they interact with it (Schmidt, 2010; Green and Li, 2011; Bell, 2011).

\subsection{Discursive Institutionalism Framework for CSR reporting}

In vitro study is not an option in social sciences. We cannot isolate certain institutional setting to study it alone in isolation from other competing logics affecting social actors concurrently. Greenwood et al. (2011) recommended that future research should address the fact of multiple institutional logics and justify explicitly which logics are incorporated into the analysis.

Incorporating both 'structure' and 'agency' in the institutional analysis is valuable in improving CSR reporting research. This incorporation is possible by looking to the institutional structure as an environment with different -and sometimes competing-institutions and multiple institutional logics, and by looking to companies as active social agents that interpret, reinterpret, translate, and reproduce institutions. Such an approach helps in understanding and explaining how new social practices like CSR reporting evolve. 
Since CSR reporting practice is not fully institutionalized yet and there are various norms, rules, roles, and practices interact within the loose boundaries of this practice, there is a good opportunity for researchers to document and draw conclusions from this interaction. Institutionalization process includes settlements that shape new practices. It is valuable for researchers to study how this 'settlement' in is reached, and why certain 'settlement' takes place in reality and not others.

Figure 1 explains a proposed framework for CSR reporting research built on 'Discursive Institutionalism'. It incorporates the concepts of 'institutional logics', 'interpretive Agents', and 'hybridity' of new practices. These components of the framework can be addressed as follows in CSR reporting research:

\subsubsection{Structural Level (Interacting and Competing Institutional Logics):}

The field of CSR reporting is influenced by different Institutional logics that interact and compete to shape CSR reporting practices. 'Profit making', 'Accountability', 'Transparency', 'Triple Bottom Line', and other notions in this field can be conceived as institutional logics since each notion of them is supported by certain institutions and compete and interact with other notions to define institutional legitimacy in the field. The outcome of this interaction and competition will be diffusion, imposing, and legitimation of various sets of rules, roles, norms, and meanings within CSR reporting practice.

\subsection{2: Agency Level (Interpretive and Active Social Agents):}

Companies, regulators, NGOs, standards-setting organizations, stakeholders, and other social agents interested in CSR reporting interact with the sets of rules, roles, norms, and meanings imposed by the institutional structure. They interpret, reinterpret, translate, and reproduce them. They may select some of these sets and neglect others, and they may borrow meanings and norms from other fields and introduce them to CSR reporting field. In most cases, these actions by different social agents are not in harmony. They will engage in discursive and political processes to shape the practice according to their interests and understandings. The outcome of the interaction between social agents will be enforcement of some sets of rules, roles, norms and meanings, omission of some, and modification of others.

\subsubsection{Practice Level (Hybrid Reporting Practices):}

The different sets of rules, roles, norms and meanings that resulted from the interactions at the structural level and the interactions at the agency level and between the two levels lead to hybrid reporting practices that include different titles, scopes, contents, discourses, genres, and standards of CSR reports and lead to various ways of producing those reports. The repetition of CSR practices will affect both levels of institutional structure and agency and may lead to the full institutionalization of certain practices in the field and the omission of others. 


\section{Figure 1: Discursive Institutionalism Theoretical Framework for CSR reporting}

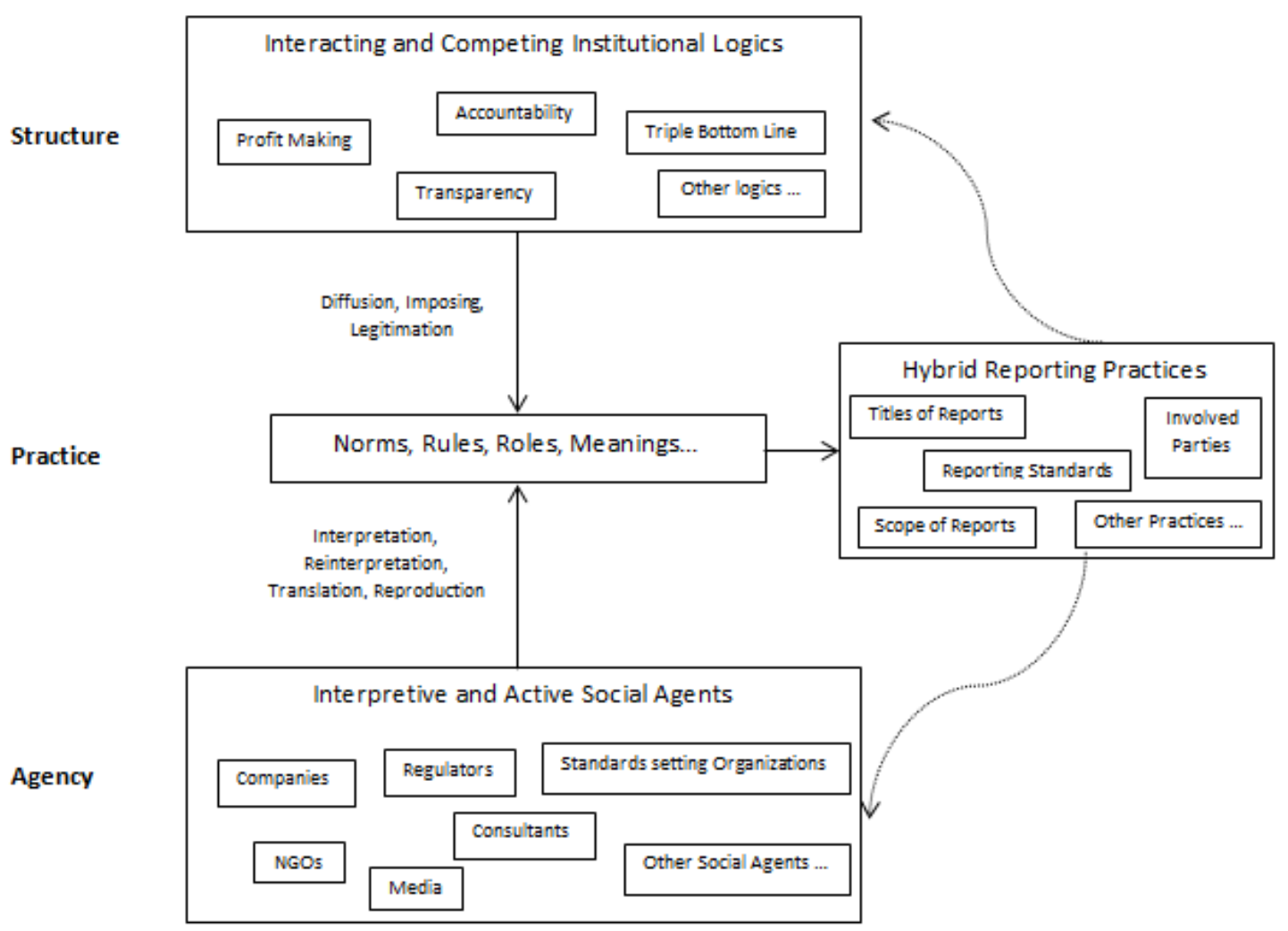

\section{Methodological Issues in Future Research:}

The proposed framework is intended to add new, novel and comprehensive research approach to the field. Quantitative content analysis is the dominant research method used in CSR reporting research. Its replication creates a concern of unnecessary effort by researchers trying to re-invent the wheel (Erosalimsky et al., 2006). Consequently, qualitative approach to analysing CSR reports started to be used in some studies, but it is not prevalent yet. There are no established traditions for qualitative analysis in this area of research.

If the research aim is to reach a comprehensive understanding and explanation of CSR reporting -which is the concern of this paper-, qualitative and -to some extent- inductive approach is more useful. However, "observed empirical data are always pre-theorised, the world is understood only through particular 'ways of seeing'" (Llewelyn, 2003, p. 666). The proposed framework in this paper provides a proper and useful 'way of seeing' when looking at CSR reporting phenomenon. However, 'proper' and 'useful' do not imply that this perspective is the only valid perspective to find the 'Truth' in this phenomenon. Rather, the underlying philosophical paradigm; ontological and epistemological positions have to be clear when approaching such a research topic qualitatively. Discovering the 'external reality' is not the main concern in social sciences; rather, the concern is to reach practically adequate and useful theorising of the studied phenomenon (Llewelyn, 2003). As Llewelyn (2003) stated, "observation itself is theory-laden. In consequence, new theories bring new objects into view and the 'same' empirical object appears differently through different theoretical 'lens'” (Llewelyn, 2003, p. 666). The proposed framework enables researchers to explain CSR reporting practices by equipping them with a broad conceptual map of the field. However, there is a need for inductive investigation of real practices to explain how these concepts and their relations are represented in reality. This explanation can be achieved by utilizing two main methodological approaches: First, Critical Discourse Analysis, and second, engagement with involved parties and reporting processes through interviews, observations and case studies. 
Critical Discourse Analysis is a research approach that analyses discourse to achieve a 'global' explanatory goal. Its concern is not only to describe texts and discourses or to explain them by looking for local and immediate causes; rather, it provides a global explanation of discourse at the higher level of social institutions (Fairclough, 2010). This comprehensive orientation fits with the framework proposed in this paper. From a Critical Discourse Analysis perspective, concepts are developed not only through actual processes of practical change but can also be shaped by discourse (Burchell and Cook, 2006).

Owen (2008) noted the growing work utilizing Critical Discourse Analysis approach in CSR reporting research to expose how companies use CSR reporting to portray radical concepts in the favour of their business as usual practices (Owen, 2008). However, Burchell and Cook (2006) highlighted the importance of approaching the CSR phenomenon by studying the different discourses within this field. Different social entities can re-interpret CSR discourse from their perspective. and there is a potential challenge lies within CSR discourse, "as actors compete in a dialectical struggle over language and meaning" (Burchell and Cook, 2006, p. 124). This discursive competition takes place at the agency level in the proposed framework in this paper. Critical Discourse Analysis can be used for better understanding of CSR discourse(s) by highlighting two key issues: First, by identifying the way in which a discourse selectively translates events around it. Second, by examining why that particular interpretation and discourse has gained predominance (Burchell and Cook, 2006) by linking it to the broader institutional context.

A relatively new concept in CDA research in the field of CSR reporting is 'Interdiscursivity'. Bhatia (2010) defines 'Interdiscursivity' as "innovative attempts to create hybrid or relatively novel constructs by appropriating or exploiting established conventions or resources associated with other genres and practices" (Bhatia, 2010, p. 35). The emphasis on 'Interdiscursivity' is of high value when utilized in a new genre like CSR reports (Bhatia 2012; Aiezza, 2015). In Fairclough's approach to CDA, there is an emphasis on the hybridity of language when different genres and discourses mix as a consequence of social fields merge (Burchell and Cook, 2006). "From this perspective, contemporary patterns of change are reflective of dialectical competition between discourses representing different interpretations and simplifications of the complex realities of modern life" (Burchell and Cook, 2006, p. 124) or representing different institutional logics interacting at the structure level according to the proposed framework.

This hybridity is evidenced in CSR reporting since it is under-developed practice with a confused state of genre allowing for flexible (or loose) adoption of various practices (Bhatia, 2012). Socio-historical context is significant in understanding how certain genres are developing and changing (Bhatia, 2010; Rutherford, 2013) and how different genres are interconnected rather than autonomous (Bremner, 2014). Therefore, the concept of 'Interdiscursivity' (Bhatia, 2010; Bhatia 2012), enables researchers to discover the hybridity in CSR reports that results from the hybridity of practices in this field.

The other approach that complements Critical Discourse Analysis is engagement with reports producers, involved parties, and reporting processes. The complexity of social phenomena requires multidisciplinary research perspective to understand its underlying mechanisms that include both structural isomorphism and agential choice, or in other words; institutional pressure and organizational dynamics (Llewelyn, 2003; Williams, 2008; Adams, 2008; Bebbington et al., 2009). Researchers' engagement in field studies complements the common tradition in this research area, i.e., analysing CSR reports content. This orientation toward research questions like: how reports are produced, who are involved in producing reports, who are the anticipated readers (or users) of these reports, how different stakeholders receive these reports, and other practice-related research questions can enrich understanding and explanation of this field with insights from real practices and the perception of involved and affected parties (Gond and Herrbach, 2006; Adams, 2008).

The required engagement can be achieved through interviews with and observations of involved parties, not only within companies but also with stakeholders like NGOs (O'Dwyer et al, 2005) and professional networks of experts and consultants in the field (Laine, 2009). These engagement methods can be combined with Discourse Analysis approach as an analytical framework (see for example: Spence, 2007). Also, longitudinal case studies that document and analyse organizational processes in different stages of reporting can provide a rigorous empirical base for any explanation of CSR reporting (see for example: Contrafatto, 2014).

These two methodological approaches; Critical Discourse Analysis and engagement with involved parties and reporting processes are useful in supporting the proposed framework with empirical findings on how the components of the framework are represented in reality and what are the mechanisms of their interactions. On the other hand, the proposed framework supports these methods by providing them with a comprehensive and holistic theoretical base. 


\section{CONCLUSIONS}

The main argument of this paper is that there is a need for a holistic and comprehensive theorising of CSR reporting phenomenon. Most previous studies were concerned with explaining companies' practices with little attention to the social and institutional context. Different perspectives were used in previous research. Among them, 'critical' and 'managerialist' perspectives agree in looking to CSR reporting as an instrumental action while differ in their normative assumptions and consequently in their explanation of the phenomenon. Institutional theory is used by some researchers in the field. However, the common approach in institutional theory-based studies is to investigate the institutional influences on companies without considering the role of these companies in interpreting and changing institutional contexts. To embed both structure and agency in CSR reporting theorizing, the paper proposes a theoretical framework based on 'Discursive Institutionalism', utilizing concepts like 'Institutional Logics', 'Social Practice Hybridity' and 'Interpretive Social Agents'. This proposed framework provides the needed holistic and comprehensive explanation of CSR reporting by incorporating the interactions that shape this practice at the structural and the agential levels and between the two levels. However, this framework provides a broad explanation. There will always be a need for detailed attention to the different concepts in the framework and how they are represented in reality. This detailed investigation can be achieved through qualitative research especially by using Critical Discourse Analysis as a methodological approach and by the engagement of researchers with involved parties in CSR reporting and their reporting processes.

\section{REFERENCES}

Adams, C.A., 2008. A commentary on: corporate social responsibility reporting and reputation risk management. Accounting, Auditing \& Accountability Journal, 21(3), pp.365-370.

Adams, C.A., 2004. The ethical, social and environmental reporting-performance portrayal gap. Accounting, Auditing \& Accountability Journal,17(5), pp.731-757.

Adams, C.A., 2002. Internal organisational factors influencing corporate social and ethical reporting: Beyond current theorising. Accounting, Auditing \& Accountability Journal, 15(2), pp.223-250.

Aiezza, M.C., 2015. "We may face the risks"..."risks that could adversely affect our face." A corpus-assisted discourse analysis of modality markers in CSR reports. Studies in Communication Sciences, 15(1), pp.68-76.

Albers, C. and Günther, T., 2010. Disclose or not disclose: determinants of social reporting for STOXX Europe 600 firms. Zeitschrift für Planung \& Unternehmenssteuerung, 21(3), pp.323-347.

Amran, A. and Siti-Nabiha, A.K., 2009. Corporate social reporting in Malaysia: a case of mimicking the West or succumbing to local pressure. Social Responsibility Journal, 5(3), pp.358-375.

Azizul Islam, M. and Deegan, C., 2008. Motivations for an organisation within a developing country to report social responsibility information: evidence from Bangladesh. Accounting, Auditing \& Accountability Journal,21(6), pp.850-874.

Bebbington, J., Higgins, C. and Frame, B., 2009. Initiating sustainable development reporting: Evidence from New Zealand. Accounting, Auditing \& Accountability Journal, 22(4), pp.588-625.

Bebbington, J., Larrinaga, C. and Moneva, J.M., 2008. Corporate social reporting and reputation risk management. Accounting, Auditing \& Accountability Journal, 21(3), pp.337-361.

Belal, A.R., 2002. Stakeholder accountability or stakeholder management: a review of UK firms' social and ethical accounting, auditing and reporting (SEAAR) practices. Corporate Social Responsibility and Environmental Management, 9(1), pp.8-25.

Bell, S., 2011. Do we really need a new 'constructivist institutionalism'to explain institutional change?. British Journal of Political Science, 41(04), pp.883-906.

Bhatia, A., 2012. The Corporate Social Responsibility Report: The Hybridization of a "Confused" Genre (2007-2011). Professional Communication, IEEE Transactions on, 55(3), pp.221-238.

Bhatia, V.K., 2010. Interdiscursivity in professional communication. Discourse \& communication, 4(1), pp.32-50.

Boiral, O. and Henri, J.F., 2017. Is sustainability performance comparable? A study of GRI reports of mining organizations. Business \& Society, p. 283-317

Bondy, K., 2008. Institutions and agency in CSR strategy: an empirical investigation of development and implementation (Doctoral dissertation, University of Nottingham).

Boxenbaum, E., 2006. Corporate social responsibility as institutional hybrids. Journal of Business Strategies, 23(1), p.45.

Branco, M.C. and Rodrigues, L.L., 2008. Factors influencing social responsibility disclosure by Portuguese companies. Journal of Business Ethics, 83(4), pp.685-701. 
Bremner, S., 2014. Genres and processes in the PR industry: Behind the scenes with an intern writer. International Journal of Business Communication, 51(3), pp.259-278.

Brown, J. and Fraser, M., 2006. Approaches and perspectives in social and environmental accounting: an overview of the conceptual landscape. Business Strategy and the Environment, 15(2), pp.103-117.

Burchell, J. and Cook, J., 2006. Confronting the "corporate citizen" Shaping the discourse of corporate social responsibility. International Journal of Sociology and Social Policy, 26(3/4), pp.121-137.

Campbell, J.L., 2007. Why would corporations behave in socially responsible ways? An institutional theory of corporate social responsibility. Academy of management Review, 32(3), pp.946-967.

Chen, S. and Bouvain, P., 2009. Is corporate responsibility converging? A comparison of corporate responsibility reporting in the USA, UK, Australia, and Germany. Journal of Business Ethics, 87(1), pp.299-317.

Chen, J.C. and Roberts, R.W., 2010. Toward a more coherent understanding of the organization-society relationship: A theoretical consideration for social and environmental accounting research. Journal of Business Ethics, 97(4), pp.651-665.

Clemens, E.S. and Cook, J.M., 1999. Politics and institutionalism: Explaining durability and change. Annual review of sociology, pp.441-466.

Contrafatto, M., 2014. The institutionalization of social and environmental reporting: An Italian narrative. Accounting, Organizations and Society, 39(6), pp.414-432.

de Villiers, C. and Alexander, D., 2014. The institutionalisation of corporate social responsibility reporting. The British Accounting Review, 46(2), pp.198-212.

Deegan, C., 2002. Introduction: the legitimising effect of social and environmental disclosures-a theoretical foundation. Accounting, Auditing \& Accountability Journal, 15(3), pp.282-311.

Erickson, S.L., Weber, M. and Segovia, J., 2011. Using communication theory to analyze corporate reporting strategies. The Journal of Business Communication (1973), 48(2), pp.207-223.

Erusalimsky, A., Gray, R. and Spence, C., 2006. Towards a more systematic study of standalone corporate social and environmental: An exploratory pilot study of UK reporting. Social and Environmental Accountability Journal, 26(1), pp.12-19.

Fairlough, N., 2010 ( $2^{\text {nd }}$ ed.). Critical discourse analysis: the critical study of language. Harlow, UK: Longman.

Fifka, M.S., 2013. Corporate Responsibility Reporting and its Determinants in Comparative Perspective-a Review of the Empirical Literature and a Meta-analysis. Business strategy and the environment, 22(1), pp.1-35.

Geppert, M., Matten, D. and Walgenbach, P., 2006. Transnational institution building and the multinational corporation: An emerging field of research. Human Relations, 59(11), pp.1451-1465.

Gond, J.P. and Herrbach, O., 2006. Social reporting as an organisational learning tool? A theoretical framework. Journal of Business Ethics, 65(4), pp.359-371.

Gray, R., 2010. Is accounting for sustainability actually accounting for sustainability... and how would we know? An exploration of narratives of organisations and the planet. Accounting, Organizations and Society, 35(1), pp.47-62.

Gray, R., 2006. Does sustainability reporting improve corporate behaviour?: Wrong question? Right time?. Accounting and Business Research, 36(sup1), pp.65-88.

Gray, R., Kouhy, R. and Lavers, S., 1995. Corporate social and environmental reporting: a review of the literature and a longitudinal study of UK disclosure. Accounting, Auditing \& Accountability Journal, 8(2), pp.47-77.

Green Jr, S.E. and Li, Y., 2011. Rhetorical institutionalism: Language, agency, and structure in institutional theory since Alvesson 1993. Journal of Management Studies, 48(7), pp.1662-1697.

Greenwood, R., Raynard, M., Kodeih, F., Micelotta, E.R. and Lounsbury, M., 2011. Institutional complexity and organizational responses. The Academy of Management Annals, 5(1), pp.317-371.

Guthrie, J. and Abeysekera, I., 2006. Content analysis of social, environmental reporting: what is new?. Journal of Human Resource Costing \& Accounting, 10(2), pp.114-126.

Hackston, D. and Milne, M.J., 1996. Some determinants of social and environmental disclosures in New Zealand companies. Accounting, Auditing \& Accountability Journal, 9(1), pp.77-108.

Hartman, L.P., Rubin, R.S. and Dhanda, K.K., 2007. The communication of corporate social responsibility: United States and European Union multinational corporations. Journal of Business Ethics, 74(4), pp.373-389.

Hooghiemstra, R., 2000. Corporate communication and impression management-new perspectives why companies engage in corporate social reporting. Journal of business ethics, 27(1-2), pp.55-68.

Idowu, S.O. and Towler, B.A., 2004. A comparative study of the contents of corporate social responsibility reports of UK companies. Management of Environmental Quality: an international journal, 15(4), pp.420-437.

Jackson, G. and Apostolakou, A., 2010. Corporate social responsibility in Western Europe: an institutional mirror or substitute?. Journal of Business Ethics, 94(3), pp.371-394. 
Jamali, D., 2010. The CSR of MNC subsidiaries in developing countries: global, local, substantive or diluted?. Journal of Business Ethics, 93(2), pp.181-200.

Laine, M., 2009. Ensuring legitimacy through rhetorical changes? A longitudinal interpretation of the environmental disclosures of a leading Finnish chemical company. Accounting, Auditing \& Accountability Journal,22(7), pp.1029-1054.

Levy, D.L., Brown, H.S. and De Jong, M., 2010. The Contested politics of corporate governance the case of the global reporting initiative. Business \& Society, 49(1), pp.88-115.

Llewelyn, S., 2003. What counts as "theory" in qualitative management and accounting research? Introducing five levels of theorizing. Accounting, Auditing \& Accountability Journal, 16(4), pp.662-708.

Manetti, Giacomo., 2011. "The quality of stakeholder engagement in sustainability reporting: empirical evidence and critical points." Corporate Social Responsibility and Environmental Management 18 (2): P. 110-122.

Marano, V., Tashman, P. and Kostova, T., 2017. Escaping the iron cage: Liabilities of origin and CSR reporting of emerging market multinational enterprises. Journal of International Business Studies, 48(3), pp.386-408.

Mathews, M.R., 1997. Twenty-five years of social and environmental accounting research: is there a silver jubilee to celebrate?. Accounting, Auditing \& Accountability Journal, 10(4), pp.481-531.

Momin, M.A. and Parker, L.D., 2013. Motivations for corporate social responsibility reporting by MNC subsidiaries in an emerging country: The case of Bangladesh. The British Accounting Review, 45(3), pp.215-228.

Morf, D., Flesher, D.L., Hayek, M., Pane, S. and Hayek, C., 2013. Shifts in corporate accountability reflected in socially responsible reporting: A historical review. Journal of Management History, 19(1), pp.87-113.

O'dwyer, B., 2002. Managerial perceptions of corporate social disclosure: An Irish story. Accounting, Auditing \& Accountability Journal, 15(3), pp.406-436.

Oliver, C., 1991. Strategic responses to institutional processes. Academy of management review, 16(1), pp.145-179.

Othman, R. and Ameer, R., 2010. Environmental disclosures of palm oil plantation companies in Malaysia: a tool for stakeholder engagement. Corporate Social Responsibility and Environmental Management, 17(1), pp.52-62.

Owen, D., 2008. Chronicles of wasted time?: A personal reflection on the current state of, and future prospects for, social and environmental accounting research. Accounting, Auditing \& Accountability Journal, 21, pp.240-267.

Parker, L.D., 2005. Social and environmental accountability research: A view from the commentary box. Accounting, Auditing \& Accountability Journal,18(6), pp.842-860.

Pedersen, E.R.G., Neergaard, P., Pedersen, J.T. and Gwozdz, W., 2013. Conformance and deviance: Company responses to institutional pressures for corporate social responsibility reporting. Business Strategy and the Environment, 22(6), pp.357-373.

Reynolds, M. and Yuthas, K., 2008. Moral discourse and corporate social responsibility reporting. Journal of Business Ethics, 78(12), pp.47-64.

Rutherford, B.A., 2013. A genre-theoretic approach to financial reporting research. The British Accounting Review, 45(4), pp.297310.

Scherer, A.G., Palazzo, G. and Seidl, D., 2013. Managing legitimacy in complex and heterogeneous environments: Sustainable development in a globalized world. Journal of Management Studies, 50(2), pp.259-284.

Schmidt, V.A., 2010. Taking ideas and discourse seriously: explaining change through discursive institutionalism as the fourth 'new institutionalism'. European political science review, 2(01), pp.1-25.

Spence, C., 2007. Social and environmental reporting and hegemonic discourse. Accounting, Auditing \& Accountability Journal, 20(6), pp.855-882.

Stanton, P. and Stanton, J., 2002. Corporate annual reports: research perspectives used. Accounting, Auditing \& Accountability Journal, 15(4), pp.478-500.

Tang, L., Gallagher, C.C. and Bie, B., 2015. Corporate social responsibility communication through corporate websites: A comparison of leading corporations in the United States and China. International Journal of Business Communication, 52(2), pp.205-227.

Tengblad, S. and Ohlsson, C., 2010. The framing of corporate social responsibility and the globalization of national business systems: A longitudinal case study. Journal of Business Ethics, 93(4), pp.653-669.

Williams, C.C., 2008. Toward a taxonomy of corporate reporting strategies. Journal of Business Communication, 45(3), pp.232264 